\title{
Circadian Phase Shifts to Neuropeptide Y In Vitro: Cellular Communication and Signal Transduction
}

\author{
Stephany M. Biello, Diego A. Golombek, Kathryn M. Schak, and Mary E. Harrington \\ Department of Psychology, Clark Science Center, Smith College, Northampton, MA 01063
}

Mammalian circadian rhythms originate in the hypothalamic suprachiasmatic nuclei (SCN), from which rhythmic neural activity can be recorded in vitro. Application of neurochemicals can reset this rhythm. Here we determine cellular correlates of the phase-shifting properties of neuropeptide $\mathrm{Y}$ (NPY) on the hamster circadian clock in vitro. Drug or control treatments were applied to hypothalamic slices containing the SCN on the first day in vitro. The firing rates of individual cells were sampled on the second day in vitro. Control slices exhibited a peak in firing rate in the middle of the day. Microdrop application of NPY to the SCN phase advanced the time of peak firing rate. This phase-shifting effect of NPY was not altered by block of sodium channels with tetrodotoxin or block of calcium channels with cadmium and nickel, consistent with a direct postsynaptic site of action. Pretreatment with the glutamate receptor antagonists (DL-2-amino-5-phosphonovaleric acid and 6-cyano-7- nitroquinoxaline-2,3-dione disodium) also did not alter phase shifts to NPY. Blocking GABA $_{A}$ receptors with bicuculline (Bic) had effects only at very high (millimolar) doses of Bic, whereas blocking $\mathrm{GABA}_{\mathrm{B}}$ receptors did not alter effects of NPY. Phase shifts to NPY were blocked by pretreatment with inhibitors of protein kinase $C(P K C)$, suggesting that PKC activation may be necessary for these effects. Bathing the slice in low $\mathrm{Ca}^{2+} /$ high $\mathrm{Mg}^{2+}$ can block phase shifts to NPY, possibly via a depolarizing action. A depolarizing high $\mathrm{K}^{+}$bath can also block NPY phase shifts. The results are consistent with direct action of NPY on pacemaker neurons, mediated through a signal transduction pathway that depends on activation of PKC.

Key words: neuropeptide Y; calcium; circadian; suprachiasmatic nucleus; PKC; hamster; GABA; TTX; phase shift; glutamate
Mammalian circadian rhythms are generated and regulated by the hypothalamic suprachiasmatic nuclei (SCN) (Rusak and Zucker, 1979; Ralph et al., 1990). SCN neurons exhibit a circadian rhythm in spontaneous activity that can be used as a marker of circadian clock output in vitro (Green and Gillette, 1982). The hypothalamic slice preparation allows recording of this rhythm for two to four cycles (Gillette, 1991; Biello et al., 1997). Typically, treatments are applied on the first day in vitro, and firing rate is monitored throughout the second day. Phase shifts are measured by the difference between the time of the peak in firing rate in treated versus control brain slice preparations.

The circadian clock can phase shift in response to photic stimuli. The phase-response curve for light shows characteristic phase delays early in the night followed by phase advances later in the night (DeCoursey, 1964). In contrast, the circadian clock is sensitive to nonphotic stimuli during the subjective day and is less sensitive or insensitive during the subjective night (Smith et al., 1992; Mrosovsky, 1995). Nonphotic phase shifts can be induced by behavioral events such as novel wheel-induced running or social interactions (Reebs and Mrosovsky, 1989).

The SCN receive input from the intergeniculate leaflet, and the

Received June 9, 1997; revised Aug. 4, 1997; accepted Aug. 11, 1997.

This study was supported by National Institutes of Health Grant NS26496 (M.E.H.), National Research Service Award NS09804 (S.M.B.), and a Howard Hughes Medical Institute stipend (K.M.S). The technical assistance of Edra Stern, Roselle Hoffmaster, and Gina Rendon is gratefully acknowledged. We are grateful to Dr. Adam Hall for helpful discussions.

Reprint requests should be addressed to Dr. Stephany Biello, Psychology Department, Adam Smith Building, Bute Gardens, University of Glasgow, Glasgow, Scotland G12 R8T.

Dr. Golombek's present address: Departamento de Fisiologia, Facultad de Medicina, Universidad de Buenos Aires, Buenos Aires 1121, Argentina.

Copyright $\odot 1997$ Society for Neuroscience $0270-6474 / 97 / 178468-08 \$ 05.00 / 0$ associated neurochemical neuropeptide Y (NPY) seems to mediate some nonphotic phase shifts of the circadian clock. Lesions of the hamster geniculohypothalamic tract block nonphotic phase shifts (Johnson et al., 1988; Biello et al., 1991; Meyer et al., 1993; Janik and Mrosovsky, 1994). NPY can induce nonphotic-type phase shifts in rats and hamsters in vivo (Albers and Ferris, 1984; Huhman and Albers, 1994; Biello and Mrosovsky, 1996) and in vitro (Shibata and Moore, 1993; Golombek et al., 1996; Biello et al., 1997; but see Medanic and Gillette, 1993). Infusion of antiserum to NPY into the area of the hamster SCN blocks phase shifts to induced activity (Biello et al., 1994). Finally, nonphotic pulses induce the expression of c-Fos in NPY-immunoreactive neurons of the intergeniculate leaflet (Janik et al., 1995).

In the hamster, we have shown that the response to NPY is dose-dependent and is mediated through Y2 receptors (Golombek et al., 1996), a result similar to that found in vivo (Huhman et al., 1996a). Although the phase-shifting effects of NPY measured in vivo in the hamster are blocked by co-inf usion with tetrodotoxin (TTX) (Huhman et al., 1996b), similar phase shifts measured in vitro in the rat are unaffected by sodium channel block, suggesting a direct postsynaptic effect on the pacemaker cell (Shibata and Moore, 1993). However, GABA transmission has also been implicated in mediating phase shifts to NPY, because co-inf usion of bicuculline (Bic) with NPY in vivo prevented the phase shift (Huhman et al., 1995).

One approach to understanding the mechanism of the clock is to follow the pathway of a phase-shifting stimulus and determine the biochemical events associated with its action. Thus, the aim of the present study is to determine the signal transduction mechanisms responsible for NPY-induced long-term modifications of the hamster circadian clock in vitro. 


\section{MATERIALS AND METHODS}

Animals and tissue preparation. Male golden hamsters (LVG, Charles River Laboratories, Wilmington, MA) (1-6 months of age) were housed in one of two rooms under opposite photoperiods, with both rooms under a schedule of $14 \mathrm{hr}$ light/10 hr dark. Lights off in the animal room was designated Zeitgeber time (ZT) 12 by convention. Hamsters were administered an overdose of halothane anesthesia and decapitated at times when this manipulation does not induce phase shifts, generally between ZT 2 and 5 (Gillette, 1986). Hypothalamic slices $(400-500 \mu \mathrm{m})$ containing the SCN were placed in a gas-fluid interface slice chamber (Medical Systems BSC with Haas top) and bathed continuously $(1 \mathrm{ml} / \mathrm{min})$ in artificial cerebrospinal fluid (ACSF) containing $125.2 \mathrm{mM} \mathrm{NaCl}, 3.8 \mathrm{~mm}$ $\mathrm{KCl}, 1.2 \mathrm{mM} \mathrm{KH}_{2} \mathrm{PO}_{4}, 1.8 \mathrm{mM} \mathrm{CaCl}_{2}, 1 \mathrm{~mm} \mathrm{MgSO}$, $24.8 \mathrm{~mm} \mathrm{NaHCO}_{3}$, $10 \mathrm{~mm}$ glucose. ACSF, pH 7.4, was supplemented with an antibiotic (gentamicin, $0.05 \mathrm{gm} / \mathrm{l}$ ) and a fungicide (amphotericin, $2 \mathrm{mg} / \mathrm{l}$ ), maintained at $34.5^{\circ} \mathrm{C}$ with warm, humidified $95 \%$ oxygen $/ 5 \%$ carbon dioxide.

Electrophysiological recording and data analysis. Extracellular single unit activity of SCN cells was detected with glass micropipette electrodes filled with either $2 \mathrm{M} \mathrm{NaCl}$ or ACSF, advanced through the slice using a hydraulic microdrive. The signal was amplified, filtered, and monitored with an oscilloscope and audio monitor. The average spontaneous firing rate (measured for $1 \mathrm{~min}$ ) and the $\mathrm{ZT}$ for each single unit encountered were recorded by an experimenter blind to all treatments. Slices without significant differences across firing rate data grouped into $1 \mathrm{hr}$ bins $(p<$ 0.05 ; ANOVA) were not used for further analysis. If there were significant differences, data were smoothed by $1 \mathrm{hr}$ running means with a 15 min lag. The time corresponding to the maximum of the smoothed data was used as the time of the peak firing. Phase shifts were measured relative to the average time of peak firing of control slices. Some of the data for control, NPY, and glutamate-treated (ZT 14) slices have been published previously (Golombek et al., 1996; Biello et al., 1997).

Drugs and treatments. Unless noted otherwise, drugs were warmed to $34.5^{\circ} \mathrm{C}$ and applied as $200 \mathrm{nl}$ microdrops to the SCN area at ZT 6, at least $1 \mathrm{hr}$ after slice preparation, using a Hamilton $1 \mu \mathrm{l}$ syringe. Recordings were performed for 6-12 hr during ZT $0-12$ of the second day in vitro. NPY was applied as a $200 \mathrm{ng} / 200 \mathrm{nl}(175 \mu \mathrm{M}$, in ACSF) drop, a dose similar to that used in in vivo studies of NPY-induced phase shifts (Biello et al., 1994). When two agents were applied there was a 5 min interval between drops.

NPY (porcine) was obtained from Bachem Bioscience (Philadelphia, PA). The cyclic nucleotide-dependent protein kinase inhibitor $\mathrm{H}-8$, the cAMP-dependent protein kinase inhibitor $\mathrm{H}-89$, the glutamate receptor antagonists DL-2-amino-5-phosphonovaleric acid (AP-5) and 6-cyano-7nitroquinoxaline-2,3-dione disodium (CNQX), and the phorbol esters phorbol 12-myristate 13-acetate (PMA) and phorbol 12,13-dibutyrate (PDBu; less hydrophobic than PMA), were all from Research Biochemicals International (Natick, MA). The protein kinase C (PKC) inhibitor chelerythrine chloride (Chel) was from LC Laboratories (Woburn, MA). The PKC inhibitors calphostin $\mathrm{C}(\mathrm{Cal})$ and bisindolylmalemide I (Bis) were from Calbiochem (La Jolla, CA). Because Cal is light-activated, the drug was not exposed to light until application to the tissue, when lights were kept on the preparation for at least $10 \mathrm{~min}$. Bicuculline methiodide, glutamate, cadmium chloride, calcium chloride, magnesium chloride, and TTX were from Sigma (St. Louis, MO). Nickel chloride was obtained from Fisher Scientific (Pittsburgh, PA). The $\mathrm{GABA}_{\mathrm{B}}$ receptor blocker CGP-35348 (CGP) was a gift from Ciba-Geigy (Basel, Switzerland). Several drugs (PMA, PDBu, CGP, Cal, Chel, H-89) were initially dissolved in DMSO and brought to final concentration with ACSF $(\leq 0.1 \%$ DMSO in the final solution in all cases except $5 \mu \mathrm{M} \mathrm{Cal}$, where the final concentration was $1 \%$ DMSO; controls showed no effect of DMSO on rhythm phase).

\section{RESULTS \\ NPY phase shifts}

Control slices receiving either no application or application of one or two ACSF microdrops at ZT 6 showed peak firing rate between ZT 6.1 and 7.3 on the subsequent day in vitro $(n=10$; mean \pm SEM, $6.7 \pm 0.1)$ (Fig. $1 A$, Table 1). An application of NPY (200 ng/200 nl) at ZT 6 on the first day in vitro induced a long-term modification in the circadian clock so that the time of peak firing occurred between ZT 2.0 and 3.7 on the second day in vitro $(n=7$; mean phase shift $\pm \mathrm{SEM}, 3.6 \pm 0.2)$ (Fig. $1 B$, Table
A.

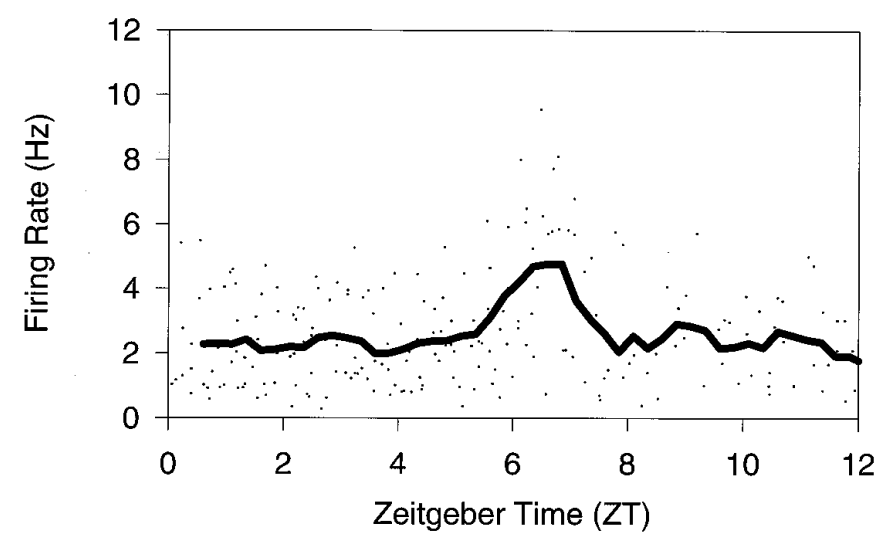

B.

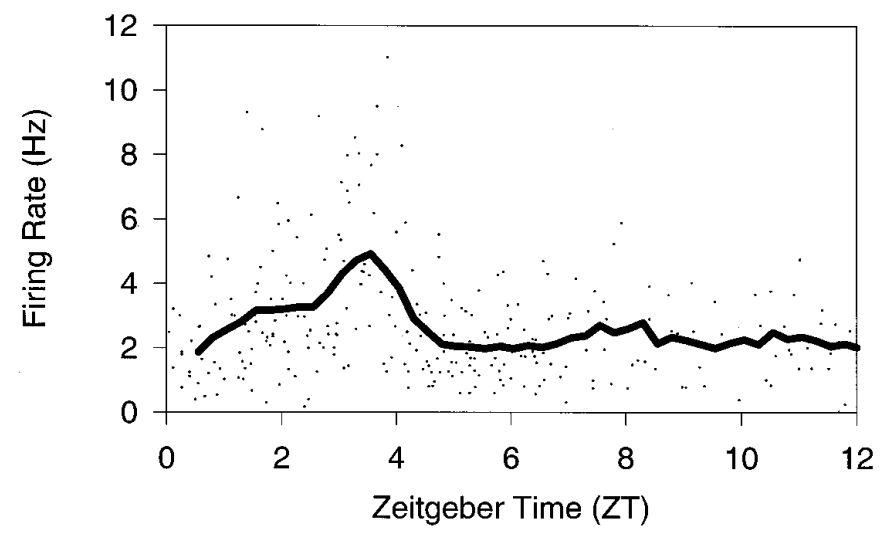

Figure 1. Average firing rate of individual SCN cells (dots) plotted against the Zeitgeber time (ZT) of recording. ZT 12 is defined as the time of lights off in the animal's previous light/dark cycle. Animals were killed between ZT 2 and ZT 10, and slices were kept in the chamber until recording the following day. The line indicates results from the running mean smoother. $A$, Results from slices receiving no application; $B$, results from slices receiving NPY $(175 \mu \mathrm{M} ; 200 \mathrm{nl})$ application at ZT 6 on day 1 in vitro.

1) and at ZT 3.4 in a slice recorded on the third day in vitro. Results were similar whether NPY was applied as a single microdrop or whether the NPY application was preceded or followed by an ACSF application (Table 1).

\section{Postsynaptic action of NPY}

Initially we performed several experiments to determine whether phase shifts induced by NPY depended on release of transmitter within the SCN (summarized in Table 2). We used TTX, a blocker of sodium channels. First, we co-applied NPY with TTX at a concentration $(1 \mu \mathrm{M}, 200 \mathrm{nl})$ that has been shown to block NPY phase shifts in vivo (Huhman et al., 1996b). This treatment in vitro did not block phase shifts to NPY, nor did a higher dose $(10 \mu \mathrm{M})$, although it suppressed firing for $\sim 3 \mathrm{hr}$ (ANOVA $F_{(2,14)}$ $=45.2 ; p<0.0001$; TTX 1 and $10 \mu \mathrm{M}+\mathrm{NPY}$ grouped and NPY not significantly different from each other, but significantly different from TTX 1 and $10 \mu \mathrm{M}+$ ACSF grouped). There was no phase-shifting effect of TTX alone. To eliminate calcium spikes and calcium-mediated neurotransmitter release, we treated slices with cadmium and nickel to block all voltage-dependent $\mathrm{Ca}^{2+}$ currents (Huang, 1993). Pretreatment with TTX (10 $\mu \mathrm{M})$, cad- 


$\begin{aligned} & \text { Table 1. Mean peak times of control slices and mean phase shifts to } \\
& \text { NPY (measured relative to the average time of peak firing of control } \\
& \text { slices) }\end{aligned}$
\begin{tabular}{llll} 
Treatment & $\begin{array}{l}\text { Number } \\
\text { of slices }\end{array}$ & $\begin{array}{l}\text { Average peak times } \\
(\mathrm{hr} \pm \mathrm{SEM})\end{array}$ & $\begin{array}{l}\text { Average phase shift } \\
(\mathrm{hr} \pm \mathrm{SEM})\end{array}$ \\
\hline $\begin{array}{l}\text { No treatment } \\
\text { ACSF }+\end{array}$ & 6 & $6.7 \pm 0.1$ & \\
ACSF & 3 & $6.8 \pm 0.2$ & \\
ACSF & 1 & 6.1 & 3.1 \\
NPY + & & & \\
ACSF & 1 & & \\
NPY alone & 3 & & $3.4 \pm 0.3$ \\
ACSF + & & & \\
NPY & 3 & &
\end{tabular}

mium $(20 \mu \mathrm{M})$, and nickel $(100 \mu \mathrm{M})$ in a $200 \mathrm{nl}$ microdrop applied before NPY did not reduce the NPY phase shift (Table 2, $\mathrm{TTX} / \mathrm{Cd} / \mathrm{Ni})$. Similarly, a $3 \mathrm{hr}$ treatment with cadmium $(20 \mu \mathrm{M})$ and nickel $(100 \mu \mathrm{M})$ in the bath (ZT 5.5-8.5), combined with a microdrop of TTX $(10 \mu \mathrm{M}, 200 \mathrm{nl} ; 5 \mathrm{~min}$ before the NPY; $\mathrm{TTX}+(\mathrm{Cd} / \mathrm{Ni}))$ did not alter the long-term effect of NPY on the circadian clock (Fig. 2, Table 2) (ANOVA $F_{(2,17)}=83.8 ; p<$ $0.0001 ; \mathrm{TTX} / \mathrm{Cd} / \mathrm{Ni}+\mathrm{NPY}, \mathrm{TTX}+(\mathrm{Cd} / \mathrm{Ni})+\mathrm{NPY}$ grouped and NPY not significantly different from each other, but significantly different from $\mathrm{TTX} / \mathrm{Cd} / \mathrm{Ni}+\mathrm{ACSF}$ and $\mathrm{TTX}+(\mathrm{Cd} / \mathrm{Ni})$ + ACSF grouped).

Previous studies in vivo suggested a role for GABA in mediating NPY phase shifts, so we investigated effects of blocking GABA receptors on NPY shifts in vitro. At high concentrations, Bic $(1.2 \mathrm{mM}, 200 \mathrm{nl})$ blocked the phase-shifting action of NPY (Table 3). This dose of Bic was similar to that shown to block NPY phase shifts in vivo (Huhman et al., 1995). However, such a high dose of Bic is associated with nonspecific effects (Olsen et al., 1978; Lester and Peck, 1979). When we reduced the dose to 100 $\mu \mathrm{M}$, Bic given as a microdrop or administered for $1 \mathrm{hr}(\mathrm{ZT}$ 5.5-6.5) in the bath did not block phase shifts to NPY. The $\mathrm{GABA}_{\mathrm{B}}$ receptor blocker CPG-35348 (CPG; $\left.100 \mu \mathrm{M} ; 200 \mathrm{nl}\right) \mathrm{did}$ not block phase shifts to NPY either (Fig. 3, Table 3). At this concentration, this drug should act as an antagonist at both $\mathrm{GABA}_{\mathrm{B}}$ R1a and -b subtypes (Kaupmann et al., 1997) [ANOVA $F_{(4,18)}=17 ; p<0.0001 ; \mathrm{NPY}+\mathrm{CGP}$ and NPY + Bic $(100 \mu \mathrm{M}$; bath and microdrop grouped) significantly different from Bic (100 $\mu \mathrm{M}$; bath) + ACSF and CGP + ACSF, but not from each other;

Table 2. Mean phase shifts to NPY or ACSF combined with tetrodotoxin (TTX) $(1 \mu \mathrm{M}$ and $10 \mu \mathrm{M})$ and TTX $(10 \mu \mathrm{M})$ microdrop + cadmium $(20 \mu \mathrm{M})+$ nickel $(100 \mu \mathrm{M})(\operatorname{microdrop} \mathrm{TTX} / \mathrm{Cd} / \mathrm{Ni}$ and bath TTX $+(\mathbf{C d} / \mathbf{N i})$ applications $)$

\begin{tabular}{lll} 
Treatment & $\begin{array}{l}\text { Number } \\
\text { of slices }\end{array}$ & $\begin{array}{l}\text { Average phase } \\
\text { shift (hr } \pm \text { SEM) }\end{array}$ \\
\hline TTX $1 \mu \mathrm{M}+\mathrm{NPY}$ & 2 & $3.3 \pm 0.3$ \\
TTX $10 \mu \mathrm{M}+\mathrm{NPY}$ & 3 & $3.2 \pm 0.4$ \\
TTX $10 \mu \mathrm{M}+\mathrm{ACSF}$ & 3 & $0.2 \pm 0.1$ \\
TTX/Cd/Ni $+\mathrm{NPY}$ & 3 & $3.3 \pm 0.1$ \\
TTX/Cd/Ni + ACSF & 3 & $0.4 \pm 0.1$ \\
TTX $+(\mathrm{Cd} / \mathrm{Ni})+\mathrm{NPY}$ & 2 & $3.5 \pm 0.5$ \\
TTX $+(\mathrm{Cd} / \mathrm{Ni})+$ ACSF & 3 & $0.5 \pm 0.1$ \\
\hline
\end{tabular}

Shifts are measured relative to the average time of peak firing of control slices.
$\mathrm{NPY}+\mathrm{CGP}$ and NPY + Bic $(100 \mu \mathrm{M}$; bath and microdrop grouped) not significantly different from NPY].

Previous studies suggested that NPY alters intracellular calcium levels through effects on glutamate transmission (van den Pol et al., 1996). To test for a similar mode of action, we applied the glutamate receptor antagonists AP-5 (100 $\mu \mathrm{M})$ and CNQX $(10 \mu \mathrm{M})$ in the bath for $1 \mathrm{hr}(\mathrm{ZT} 5.5-6.5)$ and then applied NPY at ZT 6. These antagonists did not alter phase shifts to NPY and had no phase-shifting effect by themselves (Table 4) (ANOVA $F_{(2,13)}=51.3 ; p<0.0001 ; \mathrm{AP}-5 / \mathrm{CNQX}+\mathrm{NPY}$ and NPY not significantly different from each other, but significantly different from AP-5/CNQX + ACSF). To check that the bath application of AP-5 and CNQX did indeed block glutamate receptors, we applied AP-5 and CNQX in the bath (ZT 13.5-14.5) before an application of glutamate at ZT 14. Application of glutamate (1 $\mathrm{mM} ; 200 \mathrm{nl})$ at ZT 14 induces an average phase delay in the time of peak firing of $4.5 \mathrm{hr}$ (Biello et al., 1997) $(n=5$; SEM $=0.5)$. Bath application of glutamate antagonists for $1 \mathrm{hr}$ was able to block glutamate phase shifts (Table 4) (df $=5 ; t=-14 ; p<$ $0.0001)$.

\section{NPY signal transduction}

After finding that the phase-shifting effect of NPY was consistent with a direct postsynaptic effect, we began to investigate the signal transduction events that followed application of NPY. We investigated the role of protein kinases in phase shifts to NPY. Pretreatment with a cyclic nucleotide-dependent protein kinase inhibitor $(\mathrm{H}-8 ; 200 \mathrm{nl}, 50 \mu \mathrm{M})$ did not alter the phase-shifting action of NPY $(n=3)$, nor did it induce phase shifts when administered alone $(n=3)$ (Table 5) (ANOVA $F_{(3,22)}=104 ; p<0.0001 ; \mathrm{NPY}$ and H-8+NPY different from control; H-8+ACSF not significantly different from control). Additionally, H-89 (either $200 \mathrm{nl}$ of $50 \mu \mathrm{M}$ or $1 \mathrm{hr}$ bath of $10 \mu \mathrm{M})$, a specific cAMP-dependent protein kinase inhibitor, did not affect NPY-induced phase shifts $(n=4)$ and in combination with $\operatorname{ACSF}(n=1)$ did not have any effect on the time of peak firing (Table 5) (ANOVA $F_{(2,18)}=153 ; p<$ 0.001 ; NPY and H-89 + NPY different from H-89 + ACSF but not significantly different from each other).

To test whether NPY phase shifts are mediated through activation of PKC, we blocked PKC with the specific inhibitors Chel (10 $\mu \mathrm{M}, 200 \mathrm{nl} ; n=3$ ), Cal (both 0.5 and $5 \mu \mathrm{M}, 200 \mathrm{nl} ; n=6$ ), or Bis $(0.1 \mu \mathrm{M}, 200 \mathrm{nl} ; n=3)$. These inhibitors blocked NPYinduced phase advances, without showing any effects when administered alone (Fig. 4, Table 5) [ANOVA; no significant differences between Chel + NPY, Cal $(5 \mu \mathrm{M})+\mathrm{NPY}$, Bis + NPY, Chel + ACSF, Cal $(5 \mu \mathrm{M})+\mathrm{ACSF}, \mathrm{Bis}+\mathrm{ACSF}]$. Effects of Cal seemed to be dose-dependent in that the NPY effect was blocked in only one of three slices at the lower dose tested $(0.5 \mu \mathrm{M})$ but in all three slices exposed to the higher dose $(5 \mu \mathrm{M})$. We also activated PKC through application of the phorbol esters PDBu (10 nM) and PMA (1 nM, $10 \mathrm{~nm})$. These phorbol esters induced long-term shifts in circadian clock phase similar to those induced by NPY (Table 5) (ANOVA; no significant difference between PMA $10 \mathrm{nM}, \mathrm{PDBu}$, and NPY). Effects of PMA were dosedependent and reduced by pretreatment with the PKC inhibitor Chel (10 $\mu \mathrm{M}$, PMA $10 \mathrm{nM}$; df $=7 ; t=4.1 ; p<0.005)$.

By bathing the slice in ACSF with lowered $\mathrm{Ca}^{2+}$ (to $0.05 \mathrm{mM}$ ) and increased $\mathrm{Mg}^{2+}$ (to $10 \mathrm{~mm}$ ) (Pan et al., 1992), ZT 5-7 blocked the phase advance induced by NPY at ZT 6, suggesting a role for calcium in phase shifts to NPY. The change in ACSF $\mathrm{Ca}^{2+}$ and $\mathrm{Mg}^{2+}$ levels did not affect the timing of the firing rate rhythm by itself (Fig. 2, Table 5) (ANOVA $F_{(2,13)}=22.5 ; p<$ 


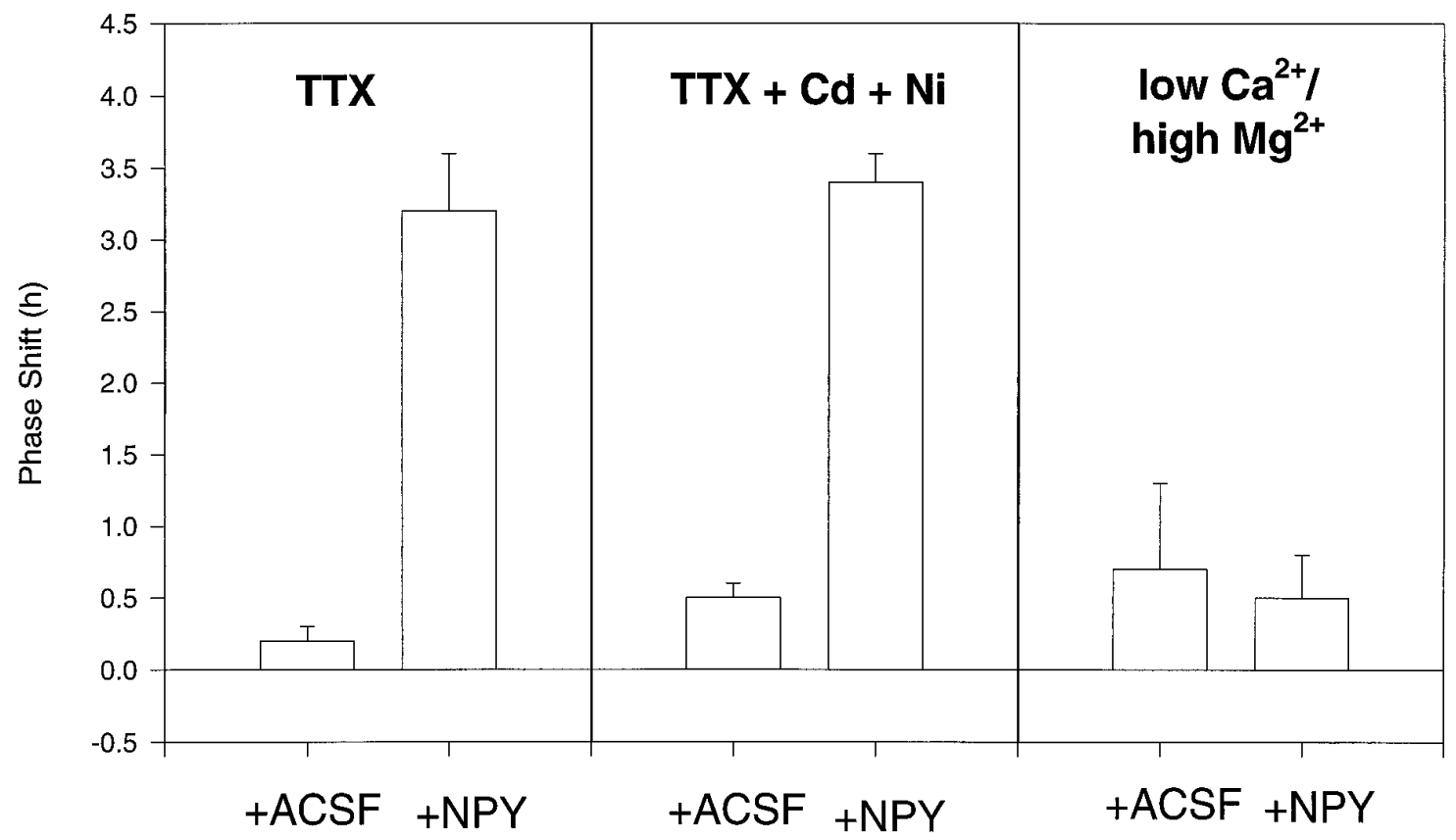

Figure 2. Histogram showing phase shifts to NPY or ACSF combined with tetrodotoxin $(T T X)(1$ and $10 \mu \mathrm{M}$ grouped $)$ and TTX $(10 \mu \mathrm{M})+$ cadmium $(20 \mu \mathrm{M})+\operatorname{nickel}(100 \mu \mathrm{M})(T T X+C d+N i)$ (bath and microdrop applications combined), or low $\mathrm{Ca}^{2+}(0.02 \mathrm{mM}) /$ high $\mathrm{Mg}^{2+}(10 \mathrm{mM})$ bath. Mean phase shifts \pm SEM.

\begin{tabular}{|c|c|c|}
\hline Treatment & $\begin{array}{l}\text { Number } \\
\text { of slices }\end{array}$ & $\begin{array}{l}\text { Average phase } \\
\text { shift (hr } \pm \text { SEM) }\end{array}$ \\
\hline Bic $(1.2 \mathrm{~mm}, 200 \mathrm{nl})+\mathrm{ACSF}$ & 3 & $0.3 \pm 0.2$ \\
\hline Bic $(1.2 \mathrm{~mm} ; 200 \mathrm{nl})+\mathrm{NPY}$ & 3 & $0.5 \pm 0.2$ \\
\hline Bic $(100 \mu \mathrm{M} ; 200 \mathrm{nl})+\mathrm{NPY}$ & 3 & $2.6 \pm 0.3$ \\
\hline Bic $(100 \mu \mathrm{M} ; 1 \mathrm{hr}$ bath $)+\mathrm{NPY}$ & 3 & $3.0 \pm 0.1$ \\
\hline Bic $(100 \mu \mathrm{M} ; 1$ hr bath $)+$ ACSF & 3 & $1.1 \pm 0.5$ \\
\hline CGP $(100 \mu \mathrm{M} ; 200 \mathrm{nl})+$ ACSF & 3 & $0.6 \pm 0.1$ \\
\hline CGP $(100 \mu \mathrm{M} ; 200 \mathrm{nl})+\mathrm{NPY}$ & 3 & $2.8 \pm 0.3$ \\
\hline
\end{tabular}

Shifts are measured relative to the average time of peak firing of control slices. Bic, Bicuculline; CPG, CPG 35348.

0.0001; low $\mathrm{Ca}^{2+} /$ high $\mathrm{Mg}^{2+}+\mathrm{NPY}$ and low $\mathrm{Ca}^{2+} /$ high $\mathrm{Mg}^{2+}$ + ACSF not significantly different from each other, but significantly different from NPY). Because this treatment would also be expected to depolarize neurons (Pan et al., 1992), we tested the effects of high $\mathrm{K}^{+}$ACSF on NPY phase shifts. Bathing of the slice in ACSF with $50 \mathrm{~mm} \mathrm{KCl}$ (and $75.2 \mathrm{~mm} \mathrm{NaCl})$ for $1 \mathrm{hr}(\mathrm{ZT}$ 5.5-6.5) blocked the NPY phase shift (Table 5). A 15 min bath of low $\mathrm{Ca}^{2+}$ and high $\mathrm{Mg}^{2+}$ ACSF centered on the time of NPY application also blocked the NPY phase shift (Table 5).

\section{DISCUSSION}

Our data are consistent with the hypothesis that NPY resets the circadian clock in vitro via a direct postsynaptic effect. Although one study reports that TTX does not block NPY-induced phase shifts in rat SCN in vitro (Shibata and Moore, 1993), other work indicates that TTX blocks in vivo NPY-induced phase shifts in hamsters (Huhman et al., 1996b). Our results support and extend the previous in vitro results, indicating that the discrepancy may arise from a difference between the in vivo and in vitro experiments and is not attributable to a species difference. We at- tempted to mimic the conditions of the previous in vivo experiments but obtained different results. Our studies indicate that the NPY-responsive SCN cells are capable of generating a permanent phase shift of the entire circadian clock, even in the absence of sodium-dependent action potentials.

Cells in the SCN show calcium spikes that are not blocked by TTX (Llinás and Hess, 1976; Huang, 1993; van den Pol and Dudek, 1993), and it was possible that these might mediate the effects of NPY. We used cadmium and nickel to block voltagegated $\mathrm{Ca}^{2+}$ currents and $\mathrm{Ca}^{2+}$ spikes as well as calciummediated neurotransmitter release and did not observe a change in the NPY effect. These experiments further indicate that the action of NPY does not require extracellular calcium influx via voltage-gated channels, because block of these channels by cadmium and nickel did not reduce the shift. Furthermore, decreased calcium influx at ZT 5.5-8.5 does not phase shift the circadian clock, because block of these channels did not produce phase shifts when given in the absence of NPY.

Previous reports have indicated a possible role for GABA in phase shifts during the subjective day. Bic, a $\mathrm{GABA}_{\mathrm{A}}$ antagonist, blocks NPY-induced phase shifts in vivo (Huhman et al., 1995), suggesting that GABAergic neurons may be targets of NPYresponsive cells or may be directly NPY-responsive, or that simultaneous activation of NPY and $\mathrm{GABA}_{\mathrm{A}}$ receptors is necessary for a phase shift. Our data suggest that this role may be minimal, because both $\mathrm{GABA}_{\mathrm{A}}$ and $\mathrm{GABA}_{\mathrm{B}}$ receptor antagonists generally do not block phase shifts to NPY. Bic is specific for $\mathrm{GABA}_{\mathrm{A}}$ receptors in the micromolar concentration range (Olsen et al., 1978; Lester and Peck, 1979), and at 10-50 $\mu \mathrm{M}$ in the bath, Bic blocks all IPSCs in rat and guinea pig SCN slices (Kim and Dudek, 1993). This would suggest that effects reported in earlier in vivo studies (Huhman et al., 1995) may be the result of a nonspecific action by millimolar concentrations of Bic. For instance, at high concentrations Bic can inhibit acetylcholinesterase activity (Frigo et al., 1987), may depolarize neurons by blocking 


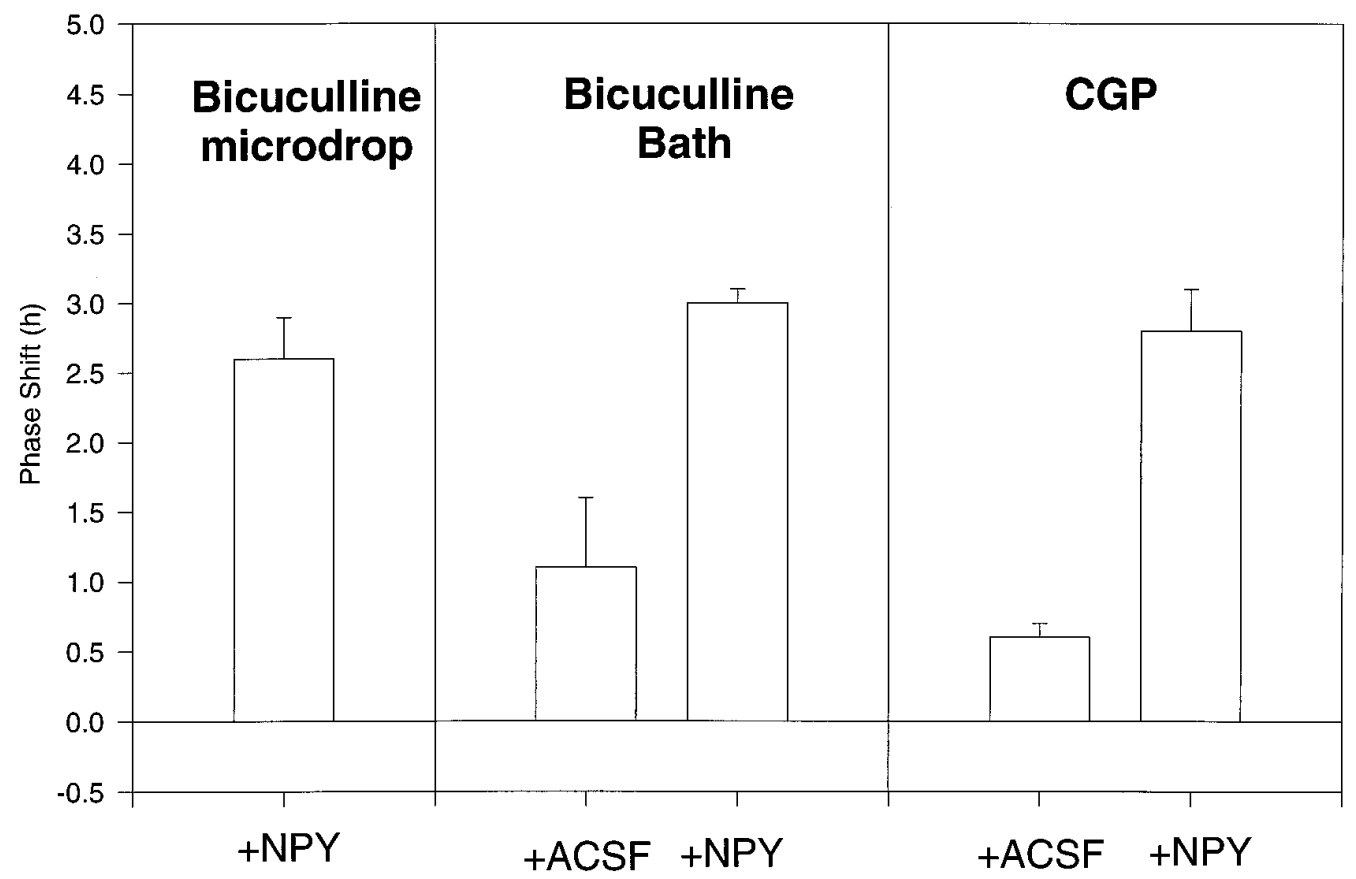

Figure 3. Histogram showing phase shifts to NPY or ACSF combined with treatments that interfere with GABA transmission, bicuculline (100 $\mu$ M), and CPG-35348 $(C P G)(100 \mu \mathrm{M})$. Mean phase shifts \pm SEM.

Table 4. Mean phase shifts to NPY or ACSF combined with substances that interfere with glutamate transmission

\begin{tabular}{llc} 
Treatment & $\begin{array}{l}\text { Number } \\
\text { of slices }\end{array}$ & $\begin{array}{c}\text { Average phase } \\
\text { shift (hr } \pm \text { SEM) }\end{array}$ \\
\hline AP-5/CNQX + ACSF(CT6) & 3 & $0.4 \pm 0.2$ \\
AP-5/CNQX + NPY(CT6) & 4 & $3.9 \pm 0.2$ \\
Glutamate (CT14) & 5 & $-4.5 \pm 0.5$ \\
AP-5/CNQX + glutamate (CT14) & 3 & $1.2 \pm 0.1$ \\
AP-5/CNQX + ACSF (CT14) & 1 & 0.4
\end{tabular}

Shifts are measured relative to the average time of peak firing of control slices Glutamate receptor blockers AP-5 $(100 \mu \mathrm{M})$ and CNQX $(10 \mu \mathrm{M})$ were applied in the bath for $1 \mathrm{hr}$.

a potassium conductance (Heyer et al., 1982), and can have other nonspecific effects (Bartolini et al., 1990).

TTX $(1 \mu \mathrm{M})$ blocks most IPSCs but does not block spontaneous EPSCs in SCN brain slices (Jiang et al., 1995a). Excitatory events in the SCN are blocked by the glutamate receptor blockers AP5 and CNQX (Kim and Dudek, 1991; van den Pol et al., 1996). However, application of these glutamate receptor blockers did not alter phase shifts to NPY, lending support to the possibility that NPY acts on a postsynaptic site.

Our results suggest that NPY resets the hamster circadian clock via activation of PKC. PKC has been identified in the SCN (Van der Zee and Bult, 1995), and NPY-induced phase shifts were mimicked by two PKC activators, the phorbol esters PMA and $\mathrm{PDBu}$. Another phorbol ester that activates PKC, 12-Otetradecanoylphorbol 13-acetate, has been shown to induce phase shifts in rat SCN in vitro. At CT6, however, these shifts were minimal, possibly attributable to a species difference (McArthur et al., 1997). NPY-induced phase shifts were blocked by pretreatment with three different inhibitors of PKC, which work by inhibiting this kinase through different specific mechanisms. Chel acts on the catalytic domain of PKC and is a noncompetitive
Table 5. Mean phase shifts to NPY or ACSF combined with substances related to protein kinases

Average phase

Treatment

Number shift

$\mathrm{H}-8(50 \mu \mathrm{M} ; 200 \mathrm{nl})+\mathrm{ACSF}$

$\mathrm{H}-8(50 \mu \mathrm{M} ; 200 \mathrm{nl})+\mathrm{NPY}$

of slices $(\mathrm{hr} \pm \mathrm{SEM})$

$\mathrm{H}-89(50 \mu \mathrm{M} ; 200 \mathrm{nl})+\mathrm{ACSF}$ and $\mathrm{H}-89(10$

$\mu \mathrm{M} ; 1 \mathrm{hr})+\mathrm{ACSF}$

$\mathrm{H}-89(50 \mu \mathrm{M} ; 200 \mathrm{nl})+\mathrm{NPY}$ and $\mathrm{H}-89(10$

$\mu \mathrm{M} ; 1 \mathrm{hr})+\mathrm{NPY}$

Chel $(10 \mu \mathrm{M} ; 200 \mathrm{nl})+$ ACSF

Chel $(10 \mu \mathrm{M} ; 200 \mathrm{nl})+\mathrm{NPY}$

Cal $(0.5 \mu \mathrm{M} ; 200 \mathrm{nl})$

$\mathrm{Cal}(0.5 \mu \mathrm{M}, 200 \mathrm{nl})+\mathrm{NPY}$

$\mathrm{Cal}(5 \mu \mathrm{M} ; 200 \mathrm{nl})+\mathrm{ACSF}$

$\mathrm{Cal}(5 \mu \mathrm{M} ; 200 \mathrm{nl})+\mathrm{NPY}$

Bis $(0.1 \mu \mathrm{M}, 200 \mathrm{nl})$ and $\operatorname{Bis}(0.1 \mu \mathrm{M} ; 200 \mathrm{nl})$

$$
+\mathrm{ACSF}
$$

$3 \quad 0.7 \pm 0.1$

$3 \quad 3.1 \pm 0.2$

Bis $(0.1 \mu \mathrm{M} ; 200 \mathrm{nl})+\mathrm{NPY}$

2

$$
0 \pm 0.8
$$

PDBu (10 nM; $200 \mathrm{nl})$ and PDBu (10 nM; 200

$$
\mathrm{nl})+\mathrm{ACSF}
$$

PMA (1 nM; $200 \mathrm{nl})$

Chel (10 $\mu \mathrm{M} ; 200 \mathrm{nl})+$ PMA (1 nM; $200 \mathrm{nl})$ and PMA (1 nM; $200 \mathrm{nl})+$ Chel $(10 \mu \mathrm{M}$;

$$
200 \mathrm{nl})
$$

PMA (10 nM; $200 \mathrm{nl})$

Chel $(10 \mu \mathrm{M} ; 200 \mathrm{nl})+$ PMA $(10 \mathrm{nM} ; 200 \mathrm{nl}) 3$ low $\mathrm{Ca}^{2+} /$ high $\mathrm{Mg}^{2+}(2 \mathrm{hr})+\mathrm{NPY}$

low $\mathrm{Ca}^{2+} /$ high $\mathrm{Mg}^{2+}(2 \mathrm{hr})+\mathrm{ACSF}$

low $\mathrm{Ca}^{2+} /$ high $\mathrm{Mg}^{2+}(15 \mathrm{~min})+\mathrm{NPY}$

high $\mathrm{K}^{+} \operatorname{ACSF}(50 \mathrm{~mm}, 1 \mathrm{hr})+\mathrm{NPY}$

Shifts are measured relative to the average time of peak firing of control slices. Chel, Chelerythrine chloride; Cal, calphostin C; Bis, bisindolylmalemide. 


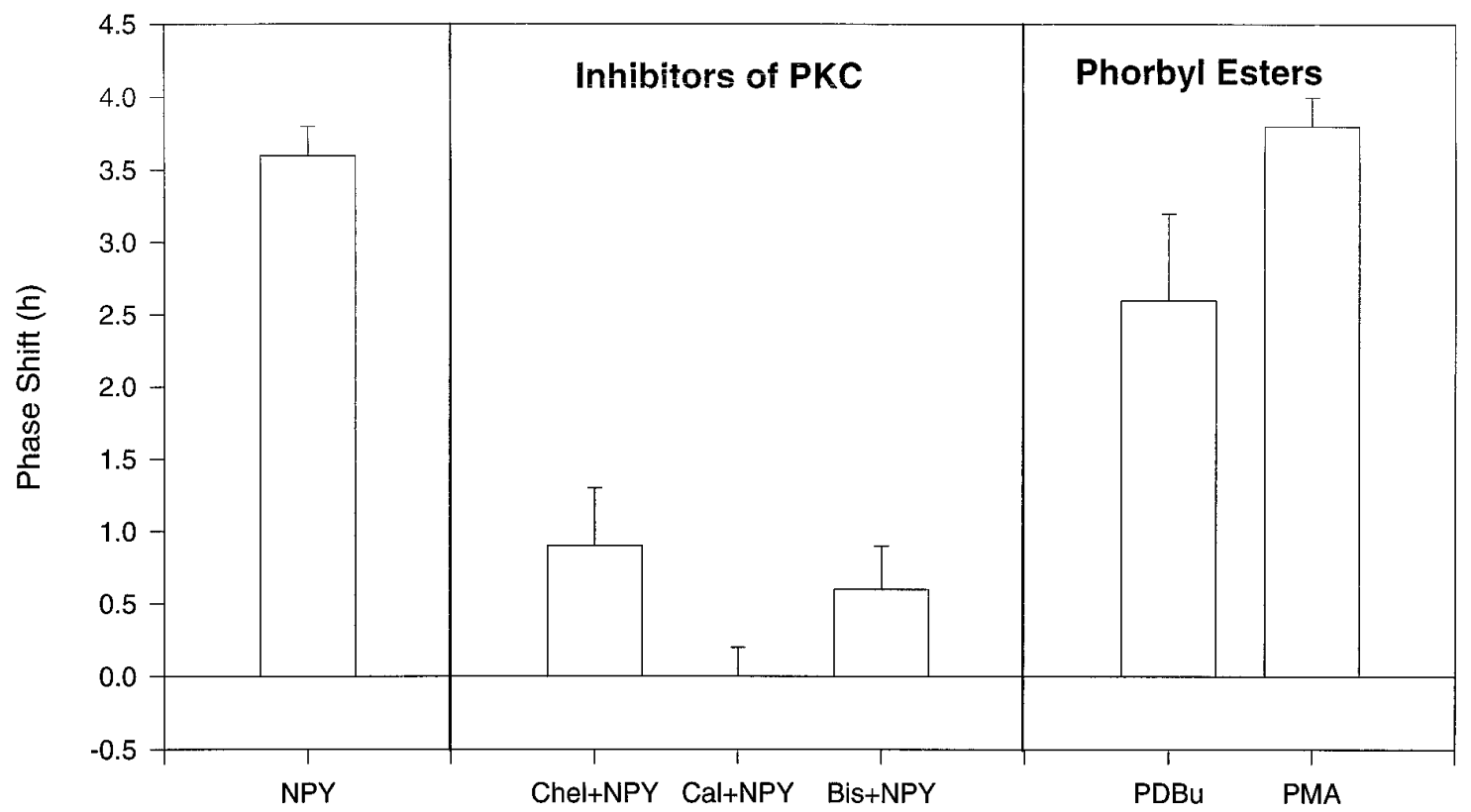

Figure 4. Histogram showing phase shifts to NPY $(175 \mu \mathrm{M})$ alone, or combined with inhibitors of PKC [chelerythrine chloride $(C h e l ; 10 \mu \mathrm{M})$, calphostin $\mathrm{C}(\mathrm{Cal} ; 5 \mu \mathrm{M})$, bisindolylmalemide I $($ Bis; $0.1 \mu \mathrm{M})$, and phase shifts to phorbol esters $(P D B u, 10 \mathrm{~nm} ; P M A, 10 \mathrm{nM})]$ at ZT 6 . Mean \pm SEM.

inhibitor with respect to ATP and a competitive inhibitor with respect to the phosphate acceptor (Jarvis et al., 1994). Cal interacts with the regulatory domain of PKC by competing at the binding site of diacylglycerol and phorbol esters (Tamaoki and Nakano, 1990). Bis acts as a competitive inhibitor for the ATP binding site on the catalytic domain of PKC (Toullec et al., 1991).

NPY did not have long-term effects on circadian rhythm phase if the slice was bathed in low $\mathrm{Ca}^{2+} /$ high $\mathrm{Mg}^{2+}$ ACSF during the time of NPY application. One explanation of this result might be that the reduction of extracellular calcium induced depletion of intracellular calcium stores (Llano et al., 1994), thus reducing the NPY activation of PKC. One concern is that the low $\mathrm{Ca}^{2+}$ conditions might affect the integrity of the NPY receptors (Parker et al., 1996), alter general cell functioning, or depolarize cells either by reducing positive surface charges on the extracellular membrane or by potentiating glutamatergic currents (Alberi et al., 1997). Low $\mathrm{Ca}^{2+} /$ high $\mathrm{Mg}^{2+} \mathrm{ACSF}$ has been reported to depolarize SCN cells (Pan et al., 1992), and depolarization might block NPY phase shifts (Biello et al., 1997). The hypothesis that low $\mathrm{Ca}^{2+} /$ high $\mathrm{Mg}^{2+}$ ACSF may act via depolarization is supported by our results showing that even a $15 \mathrm{~min}$ bath of low $\mathrm{Ca}^{2+} /$ high $\mathrm{Mg}^{2+}$ ACSF can block NPY phase shifts, and that a depolarizing high $\mathrm{K}^{+}$bath has a similar effect.

Nonphotic stimuli do not seem to be using a single signal transduction pathway to reach the circadian clock. Although NPY and serotonin are similar in that both shift the clock even when cells are bathed in TTX (Prosser et al., 1992; this paper), NPY and serotonin induce nonphotic phase shifts via different signal transduction pathways. NPY seems to activate PKC, whereas serotonin-mediated phase shifting in the rat is dependent on activity of cAMP-dependent protein kinase (Prosser et al., 1994). Because these two neurotransmitters induce phase shifts in similar patterns, it is plausible that their signal transduction pathways converge at some point. Interestingly, both NPY and serotonin phase shifts seem to depend on $\mathrm{K}^{+}$channel activation (Prosser et al., 1994; Hall and Harrington, 1996; our unpublished results). Melatonin also phase shifts the circadian clock in the subjective day and seems to use PKC (McArthur et al., 1997); effects of melatonin on $\mathrm{K}^{+}$channels, however, are observed only at concentrations well above those necessary for phase shifting (Jiang et al., 1995b).

Various NPY receptor types function in the SCN. Although Y2 receptors mediate phase shifts to NPY both in vivo (Huhman et al., 1996a) and in vitro (Golombek et al., 1996), NPY blocks pituitary adenylate cyclase-activating peptide phase shifts via a receptor other than the Y2 receptor (Harrington and Hoque, 1997).

NPY induces long-term depression in both electrical activity and glutamate-evoked increases in intracellular calcium levels in mature rat SCN cultures and slices (van den Pol et al., 1996) or GABA-evoked increases in less mature cultures (Obrietan and van den Pol, 1996). These effects are largely mediated presynaptically, by both Y1 and Y2 NPY receptor subtypes (Chen and van den Pol, 1996; Obrietan and van den Pol, 1996; van den Pol et al., 1996). All of these long-term effects of NPY in the rat SCN are abolished in the presence of AP5 and CNQX (van den Pol et al., 1996). Because NPY can phase shift the hamster SCN in the presence of AP5 and CNQX, the long-term effects of NPY on intracellular free calcium (van den Pol et al., 1996) may not be related to phase shifting. Furthermore, although SCN neurons dramatically increase firing rate around ZT 6, our experiments demonstrate that block of calcium channels and ionotropic glutamate receptors has no effect on the time of peak firing on the subsequent cycle. Thus, the intracellular calcium level may not be an integral clock component at ZT 6 . Interestingly, the only response to NPY that persisted when AP5/CNQX was included in van den Pol's studies was a brief hyperpolarization of the postsynaptic membrane.

These data suggest a general model for the mechanism of nonphotic phase shifting of the circadian clock. Because both NPY and serotonin seem to activate protein kinases, one might hypothesize that either PKA or PKC can phosphorylate a putative clock protein. Phosphorylation might act to induce nuclear translocation of a protein, similar to circadian systems studied in 
Drosophila and Neurospora (Edery et al., 1994; Garceau et al., 1997). In both systems, it is thought that nuclear translocation of clock protein(s) allows initiation of a negative feedback loop, by which these proteins negatively regulate their own gene's transcription (Hardin et al., 1990; Aronson et al., 1994). If a similar system were underlying the mammalian clock, one might predict that the clock protein is normally phosphorylated late in the subjective day, thus reducing the ability of NPY and serotonin to phase shift. From this, a further prediction would be that PKA or PKC inhibitors would delay the clock if applied during this time; preliminary data supporting this has been reported (Prosser et al., 1994).

Although there is some understanding of the intracellular mechanisms leading to photic entrainment of circadian rhythms, little is known about the events leading to nonphotic stimulation of the clock. The present study is the first to present data on the signal transduction pathways required for NPY-induced phase shifts in the Syrian hamster. Our data are consistent with the hypothesis that the effects of NPY are postsynaptic and depend on PKC. Although this is unusual for an NPY receptor, which is more commonly linked with inhibition of adenylate cyclase, it is similar to reported effects of melatonin on circadian clock tissue. These results should stimulate further work examining links between NPY and PKC in other systems, as well as possible links between the actions of NPY and melatonin.

\section{REFERENCES}

Alberi S, Dubois-Dauphin M, Dreif uss JJ, Raggenbass M (1997) Wholecell NMDA-evoked current in suprachiasmatic neurones of the rat: modulation by extracellular calcium ions. Brain Res 745:55-66.

Albers HE, Ferris CF (1984) Neuropeptide Y: role in light-dark cycle entrainment of hamster circadian rhythms. Neurosci Lett 50:163-168.

Aronson BD, Johnson KA, Loros JJ, Dunlap JC (1994) Negative feedback defining a circadian clock: autoregulation of the clock gene frequency. Science 263:1578-1584.

Bartolini A, Giotti A, Giuliani S, Malmberg-Aiello P, Patacchini R (1990) Bicuculline actions on isolated rat atria, mouse vas-deferens and guinea-pig ileum are unrelated to GABA A receptor blockade. Gen Pharmacol 21:277-284.

Biello SM, Mrosovsky N (1996) Phase response curves to neuropeptide $\mathrm{Y}$ in wildtype and tau mutant hamsters. J Biol Rhythms 11:27-34.

Biello SM, Harrington ME, Mason R (1991) Geniculo-hypothalamic tract lesions block chlordiazepoxide-induced phase advances in Syrian hamsters. Brain Res 552:47-52.

Biello SM, Janik D, Mrosovsky NM, (1994) Neuropeptide Y and behaviorally induced phase shifts. Neuroscience 62:273-279.

Biello SM, Golombek DA, Harrington ME (1997) Neuropeptide Y and glutamate block each other's phase shifts in the suprachiasmatic nucleus in in vitro. Neuroscience 77:1049-1058.

Chen G, van den Pol AN (1996) Multiple NPY receptors coexist in preand postsynaptic sites: inhibition of GABA release in isolated selfinnervating SCN neurons. J Neurosci 16:7711-7724.

DeCoursey P (1964) Function of a light response rhythm in hamsters. J Cell Comp Physiol 63:189-196.

Edery I, Zweibel L, Dembinska M, Rosbash M (1994) Temporal phosphorylation of the Drosophila period protein. Proc Natl Acad Sci USA 91:2260-2264.

Frigo GM, Galli A, Lecchini S, Marcoli M (1987) A facilitatory effect of bicuculline on the enteric neurones in the guinea-pig isolated colon. Br J Pharmacol 90:31-41.

Garceau NY, Liu Y, Loros JJ, Dunlap JC (1997) Alternative initiation of translation and time-specific phosphorylation yield multiple forms of the essential clock protein FREQUENCY. Cell 89:469-476.

Gillette MU (1986) The suprachiasmatic nuclei: circadian phase-shifts induced at the time of hypothalamic slice preparation are preserved in vitro. Brain Res 379:176-181.

Gillette MU (1991) SCN electrophysiology in vitro. In: SCN: the mind's clock (Klein DC, Moore RY, Reppert SM, eds), pp 125-143. New York: Oxford UP.
Golombek DA, Biello SM, Harrington ME (1996) Neuropeptide Y phase shifts the circadian clock via a Y2 receptor. NeuroReport 7:1315-1319.

Green DJ, Gillette R (1982) Circadian rhythm of firing rate recorded from single cells in the rat suprachiasmatic brain slice. Brain Res 245:198-200.

Hall AC, Harrington ME (1996) Neuropeptide Y activates large conductance channels in suprachiasmatic nuclei (SCN) neurons. Soc Neurosci Abstr 22:2055.

Hardin PE, Hall JC, Rosbash M (1990) Feedback of the Drosophila period gene product on circadian cycling of its messenger RNA levels. Nature 343:536-540.

Harrington ME, Hoque S (1997) NPY opposes PACAP phase shifts via receptors different from those involved in NPY phase shifts. NeuroReport 8:2677-2680.

Heyer EJ, Nowak LM, MacDonald RL (1982) Membrane depolarization and prolongation of calcium-dependent action potentials of mouse neurons in cell culture by two convulsants: bicuculline and penicillin. Brain Res 232:41-56.

Huang R (1993) Sodium and calcium currents in acutely dissociated neurons from rat suprachiasmatic nucleus. J Neurophysiol 70:1692-1703.

Huhman KL, Albers HE (1994) Neuropeptide Y microinjected into the suprachiasmatic region phase shifts circadian rhythms in constant darkness. Peptides 15:1475-1478.

Huhman KL, Babagbemi TO, Albers HE (1995) Bicuculline blocks neuropeptide Y-induced phase advances when microinjected in the suprachiasmatic nucleus of Syrian hamsters. Brain Res 675:333-336.

Huhman KL, Gillespie CF, Marvel CL, Albers HE (1996a) Neuropeptide $\mathrm{Y}$ phase shifts circadian rhythms in vivo via a Y2 receptor. NeuroReport 7:1249-1252.

Huhman KL, Gillespie CF, Marvel CL, Mintz EM, Albers HE (1996b) The phase shifting effects of NPY, but not Muscimol, require sodium dependent synaptic transmission in the SCN. Soc Res Biol Rhythms 5:54.

Janik D, Mrosovsky N (1994) Intergeniculate leaflet lesions and behaviorally-induced shifts of circadian rhythms. Brain Res 651:174-182.

Janik D, Mikkelsen JD, Mrosovsky N (1995) Cellular colocalization of Fos and neuropeptide $\mathrm{Y}$ in the intergeniculate leaflet after nonphotic phase shifting events. Brain Res 698:137-145.

Jarvis WD, Turner AJ, Povirk LF, Traylor RS, Grant S (1994) Induction of apoptotic DNA fragmentation and cell death in HL-60 human promyelocytic leukemia cells by pharmacological inhibitors of protein kinase C. Cancer Res 70:381-386.

Jiang ZG, Allen CN, North RA (1995a) Presynaptic inhibition by baclofen of retinohypothalamic excitatory synaptic transmission in rat suprachiasmatic nucleus. Neuroscience 64:813-819.

Jiang ZG, Nelson CS, Allen CN (1995b) Melatonin activates an outward current and inhibits $\mathrm{Ih}$ in rat suprachiasmatic nucleus neurons. Brain Res 687:125-132.

Johnson RF, Smale L, Moore RY, Morin LP (1988) Lateral geniculate lesions block circadian phase-shift responses to a benzodiazepine. Proc Natl Acad Sci USA 85:5301-5304.

Kaupmann K, Huggel K, Heid J, Flor PJ, Bischoff S, Mickel SJ, McMaster G, Angst C, Bittiger H, Froesti W, Bettler B (1997) Expression cloning of GABAB receptors uncovers similarity to metabotropic glutamate receptors. Nature 386:239-246.

Kim YI, Dudek FE (1991) Intracellular electrophysiological study of suprachiasmatic nucleus neurones in rodents: excitatory synaptic mechanisms. J Physiol (Lond) 444:269-287.

Kim YI, Dudek FE (1993) Membrane properties of rat suprachiasmatic nucleus neurons receiving optic nerve input. J Physiol (Lond) 464:229-243.

Lester BR, Peck EJ (1979) Kinetic and pharmacological characterization of gamma aminobutyric acid receptive sites from mammalian brain. Brain Res 161:79-97.

Llano L, DiPolo R, Marty A (1994) Calcium-induced calcium release in cerebellar purkinje cells. Neuron 12:663-673.

Llinás R, Hess R (1976) Tetrodotoxin-resistant dendritic spikes in avian Purkinje cells. Proc Natl Acad Sci USA 73:2520-2523.

McArthur AJ, Hunt AE, Gillette MU (1997) Melatonin action and signal transduction in the rat suprachiasmatic circadian clock: activation of protein kinase C at dusk and dawn. Endocrinology 138:627-634.

Medanic M, Gillette MU (1993) Suprachiasmatic circadian pacemaker of the rat shows two windows of sensitivity to neuropeptide y in vitro. Brain Res 620:281-286.

Meyer EL, Harrington ME, Rahamani T (1993) A phase-response curve 
to the benzodiazepine chlordiazepoxide and the effect of geniculohypothalamic tract ablation. Physiol Behav 53:237-243.

Mrosovsky N (1995) A non-photic gateway to the circadian clock of hamsters. Ciba Found Symp 183:154-167.

Obrietan K, van den Pol AN (1996) Neuropeptide Y depresses GABAmediated calcium transients in developing suprachiasmatic nucleus neurons: a novel form of calcium long-term depression. J Neurosci 16:3521-3533.

Olsen RW, Ticku MK, Van Ness PC, Greenlee D (1978) Effects of drugs on $\gamma$-aminobutyric acid receptors, uptake, release and synthesis in vitro. Brain Res 139:277-296.

Parker MS, Crowley WR, Parker SL (1996) Differences in cation sensitivity of ligand binding to $\mathrm{Y}_{1}$ and $\mathrm{Y}_{2}$ subtype of neuropeptide $\mathrm{Y}$ (NPY) receptor of rat brain. Soc Neurosci Abstr 22:1548.

Pan J-T, Li C-S, Tang K-C, Lin J-Y (1992) Low calcium-high magnesium increases activities of hypothalamic arcuate and suprachiasmatic neurons in brain slices. Neurosci Lett 144:157-160.

Prosser RA, Heller HC, Miller JD (1992) Serotonergic phase shifts of the mammalian circadian clock: effects of tetrodotoxin and high $\mathrm{Mg} 2+$. Brain Res 573:336-340.

Prosser RA, Heller HC, Miller JD (1994) Serotonergic phase advances of the mammalian circadian clock involve protein kinase $\mathrm{A}$ and $\mathrm{K}^{+}$ channel opening. Brain Res 644:67-73.

Ralph MR, Foster RG, Davis FC, Menaker M (1990) Transplanted suprachiasmatic nucleus determines circadian period. Science 247:975-978.
Reebs SG, Mrosovsky N (1989) Effects of induced wheel running on the circadian activity rhythms of Syrian hamsters: entrainment and phase response curve. J Biol Rhythms 4:39-48.

Rusak B, Zucker I (1979) Neural regulation of circadian rhythms. Physiol Rev 59:449-527.

Shibata S, Moore RY (1993) Neuropeptide Y and optic chiasm stimulation affect suprachiasmatic nucleus circadian function in vitro. Brain Res 615:95-100.

Smith RD, Turek FW, Takahashi JS (1992) Two families of phaseresponse curves characterize the resetting of the hamster circadian clock. Am J Physiol 262:R1149-1153.

Tamaoki T, Nakano H (1990) Potent and specific inhibitors of protein kinase $\mathrm{C}$ of microbial origin. Biotechnology 8:732-735.

Toullec D, Pianetti P, Coste H, Bellevergue P, Grand-Perret T, Ajakane M, Baudet V, Boissin P, Boursier E, Loriolle F (1991) The bisindolylmaleimide GF $109203 \mathrm{X}$ is a potent and selective inhibitor of protein kinase C. J Biol Chem 266:15771-15781.

van den Pol AN, Dudek FE (1993) Cellular communication in the circadian clock, the suprachiasmatic nucleus. Neuroscience 56:793-811.

van den Pol AN, Obrietan K, Chen G, Belousov AB (1996) Neuropeptide Y-mediated long-term depression of excitatory activity in suprachiasmatic nucleus neurons. J Neurosci 16:5883-5895.

Van der Zee EA, Bult A (1995) Distribution of AVP and Ca(2+)dependent PKC-isozymes in the suprachiasmatic nucleus of the mouse and rabbit. Brain Res 701:99-107. 